\title{
Ni-based Catalyst Supported on Mesostructured Silica Nanoparticles (MSN) for Methanol Oxidation Reaction (MOR)
}

\author{
(Mangkin Berasaskan Ni Disokong oleh Silika Nanopartikel Mesostruktur (MSN) untuk \\ Tindak Balas Pengoksidaan Metanol) \\ Muliani Mansor ${ }^{\mathrm{a}}$, Sharifah Najiha Timmiati, ${ }^{\mathrm{a},}$, Kean Long Limª, Azran Mohd Zainoodina, Nur Hidayatul Nazirah Kamarudin ${ }^{\mathrm{b}}$ \\ ${ }^{a}$ Fuel Cell Institute \\ ${ }^{b}$ Research Center for Sustainable Process Technology (CESPRO), Faculty of Engineering \& Built Environment \\ Universiti Kebangsaan Malaysia, Malaysia
}

\begin{abstract}
A new catalyst based on mesostructured silica nanoparticle (5wt\%, 20wt $\%$, and $30 w t \% \mathrm{Ni}$-MSN) were prepared by the wet impregnation method and used for electro-oxidation of methanol. While, MSN as a catalyst support was synthesized using co-condensation and sol-gel method. The synthesized MSN and Ni-MSN were characterized using X-ray diffraction (XRD), field emission scanning electron microscopy (FESEM), and Fourier Transform Infra-red (FTIR) techniques. Ni-MSN catalysts were successfully prepared by mixing with the conducting graphite in 1:1 ratio which called carbon paste electrode (CPE). Mixing with graphite, in this work, was particular necessary to increase the electrical conductivity of the Ni-MSN materials. For fuel cell applications, the electrochemical measurements for methanol oxidation were investigated using cyclic voltammetry (CV) and chronoamperometry (CA) in $1.0 \mathrm{M} \mathrm{NaOH}$ and $1.0 \mathrm{M} \mathrm{CH}_{3} \mathrm{OH}$ for modified electrode, Ni-MSNCPE. Among the three samples, 30wt\% Ni-MSNCPE exhibits a high current density $\left(\sim 8 \mathrm{~mA} \mathrm{~cm}^{-2}\right)$ and long-term chronoamperometry stability (3600 s) toward methanol oxidation in alkaline solution. This may attribute to the high dispersion of nickel and ordered mesoporous structure which can facilitate the diffusion of methanol and products. 30wt\% Ni nanoparticles supported onto MSN catalyst demonstrate better electrocatalytic activity and stability than the 5wt\% and 20wt\% Ni-MSNCPE catalysts.
\end{abstract}

Keywords: Mesostructured Silica Nanoparticle; anode catalyst; methanol oxidation reaction; modified electrode

ABSTRAK

Mangkin baru berasaskan mesostruktur silika nanopartikel (5wt\%, 20wt\%, and 30wt\% Ni-MSN) disediakan dengan menggunakan kaedah pengisitepuan basah dan digunakan untuk pengelektrooksidaan metanol. Manakala, MSN sebagai mangkin sokongan disintesis menggunakan kaedah kondensasi bersama dan sol-gel. MSN dan Ni-MSN yang disintesis dicirikan dengan menggunakan pembelauan sinar-X (XRD), mikroskop imbasan elektron pancaran medan (FESEM), dan Infra Merah Jelmaan Fourier (FTIR). Mangkin Ni-MSN telah berjaya disediakan dengan mencampurkan grafit yang bersifat konduksi dengan nisbah 1:1 yang dikenali sebagai elektrod pes karbon (CPE). Percampuran dengan grafit, dalam kerja ini, sangat diperlukan untuk meningkatkan kekonduksian elektrik bahan Ni-MSN. Untuk aplikasi sel fuel, pengukuran elektrokimia bagi pengoksidaan metanol dikaji menggunakan voltammetri berkitar (CV) dan kronoamperometri (CA) di dalam $1.0 \mathrm{M} \mathrm{NaOH}$ dan $1.0 \mathrm{M} \mathrm{CH}_{3} \mathrm{OH}$ untuk elektrod yang diubah suai, Ni-MSNCPE. Antara ketiga-tiga sampel, 30wt\% Ni-MSNCPE menunjukkan ketumpatan arus yang tinggi ( $8 \mathrm{~mA} \mathrm{~cm}^{-2}$ ) dan kestabilan jangka panjang kronoamperometri (3600 s) terhadap pengoksidaan metanol di dalam larutan alkali. Ini mungkin disebabkan oleh penyebaran nikel yang tinggi dan struktur berliang meso yang tersusun yang memudahkan resapan metanol dan hasil. Mangkin 30wt\% Ni nanopartikel yang disokong ke MSN menunjukkan aktiviti dan kestabilan elektromangkin yang lebih baik berbanding mangkin 5wt\% dan 20wt\% Ni-MSNCPE.

Kata kunci: Mesostruktur silika nanopartikel; mangkin anod; tindak balas pengoksidaan methanol; elektrod diubah suai

\section{INTRODUCTION}

In recent years, direct methanol fuel cells (DMFCs) have garnered great attention as power sources due to their several advantages of using methanol as a fuel which has low operating temperature and better safety, higher energy density $(3800 \mathrm{kcal} / \mathrm{l})$ than hydrogen $(658 \mathrm{kcal} / 1$ used as the fuel in proton exchange membrane fuel cells), and ease of handling methanol (than $\mathrm{H}_{2}$ ) (Zainoodin, Kamarudin \& Daud 2010). However, their commercial success is yet to be proven and significantly depends on two factors: the high cost associated with precious metal electrocatalysts (for example, $\mathrm{Pt}$ ) and enhancements in the catalytic activity at the anode (Kamarudin et al. 2006; Patel et al. 2015; Ting et 
al. 2016; Zhao et al. 2011). Thus, the great progress towards non Pt-based has been made recently. The usability of non $\mathrm{Pt}-$ based catalyst have received intensive research attention in alkaline medium because of a less corrosive environment. Besides that, it also can improved reaction kinetics (L. Wang et al. 2016), enhanced kinetics of electrocatalytic oxidation of methanol at low anodic overpotential (Antolini \& Gonzalez 2010), and reduced the adsorption of CO intermediates that might limit electrocatalysis (Peng, Sun \& Asiri 2015). Nevertheless, it still remains an enormous challenge to develop low-cost anodic catalysts with superior activity and stability to replace Pt-based catalysts (Liu, Chen \& Zhu 2016).

Nickel-based anode catalyst is one of the alternatives promising catalyst to $\mathrm{Pt}-$ based catalysts because of it has high electrocatalytic activity performance, good stability, and low poisoning effect as well as reduced cost. Particularly, Ni-based catalysts, such as metallic Ni (Rahim 2004), Ni alloy (Danaee et al. 2010), Ni(OH) (El-Shafei 1999) and NiO (Tong et al. 2016), are the most extensively studied Ni-based catalysts in alkaline DMFCs. The role of $\mathrm{Ni}$ in all previous studies shows that it has good surface oxidation properties to increase the electrocatalytic activity. In 2014, Hassan et al. (Hassan et al. 2014) prepared Ni-MCM41 catalysts for methanol oxidation reaction (MOR) in alkaline medium. He found that Ni catalyst has very small or negligible poisoning effect as it contains many pores and channel which permit easier removal of the oxidation products.

Catalyst support material plays a vital role to improve the fuel cell performance; carbon-based and silica-based materials have been widely investigated as support material for anode catalyst in DMFCs. Therefore, it is important to select suitable support material to enhance the performance of the catalyst. At present, mesostructured silica nanoparticle (MSN) has attracted great fundamental and applied research efforts due to its excellent properties such as large surface area $(>1000$ $\mathrm{m}^{2} \mathrm{~g}^{-1}$ ), thermal and mechanical stability, highly uniform pore size distribution, tunable pore size, high adsorption capacity and excellent dispersibility in aqueous media as a support material for the catalyst in DMFCs (Karim et al. 2012; Karim et al. 2014). However, MSN has low electrical conductivity and resulted in high electrical resistance in the reaction, which affects the performance of methanol oxidation. Thus, to increase the electrical conductivity of the catalysts, carbon paste electrode (CPE) that so-called modified electrode is introduced.

So far no work has been reported on the application of Ni/MSN modified electrode as anodes catalysts for DMFC applications. In this paper, Ni catalyst supported on MSN was prepared using wet impregnation method. Then, the synthesized electrocatalysts were characterized using Xray diffraction (XRD), field emission scanning electron microscopy (FESEM), energy dispersive X-ray (EDX) and Fourier transform Infra-red (FTIR). Electro-oxidation of methanol is investigated using cyclic voltammetry (CV) and chronoamperometry (CA) techniques. This work will provide a promising solution to replace the $\mathrm{Pt}-$ based catalysts as anodes for alkaline DMFCs in order to reduce costs.

\section{METHODOLOGY}

SYNTHESIS OF MSN

MSN was synthesized using co-condensation and sol-gel method according to the previous report (Aziz et al. 2014; Karim et al. 2014). Briefly, СТАВ surfactant (4.68 g), EG solvent $(120 \mathrm{ml})$ and $\mathrm{NH}_{4} \mathrm{OH}$ solution $(29 \mathrm{ml})$ were dissolved in $720 \mathrm{ml}$ of DI water. After vigorous stirring for approximately $30 \mathrm{~min}$ at $323 \mathrm{~K}$, TEOS $(5.7 \mathrm{ml})$ and APTES $(1.052 \mathrm{ml})$ were added to the clear mixture to give a white suspension solution. This solution was stirred for an additional $2 \mathrm{~h}$ at $353 \mathrm{~K}$. The resulting mixture allowed to rest for $24 \mathrm{~h}$ in the refrigerator until it completely separates into two layers. Then, the samples were collected by centrifugation at $5000 \mathrm{rpm}$ for 10 min and washed with DI water and absolute ethanol (1:1) 5 times. The synthesized MSN were dried overnight at $383 \mathrm{~K}$ and calcined at $823 \mathrm{~K}$ for $3 \mathrm{~h}$ to remove the surfactant.

SYNTHESIS OF NI/MSN

$\mathrm{Ni}$ /MSNs electrocatalyst were prepared by the wet impregnation method (Aziz et al. 2014; Aziz et al. 2014). The aqueous nickel nitrate $\left(\mathrm{Ni}\left(\mathrm{NO}_{3}\right)_{2} \cdot 6 \mathrm{H}_{2} \mathrm{O}\right)$ were impregnated on the support (MSN) at $353 \mathrm{~K}$. Then, the sample was dried in the oven at $383 \mathrm{~K}$ overnight before calcination in air at $823 \mathrm{~K}$ for $3 \mathrm{~h}$.

\section{ELECTRODE PREPARATION}

Electrocatalytic inks were prepared by mixing $30 \mathrm{mg}$ of the catalyst and $30 \mathrm{mg}$ graphite powder with $200 \mu \mathrm{L}$ of $5 \mathrm{wt} . \%$ Nafion ${ }^{\circledR} 117$ and $800 \mu \mathrm{L}$ 2-propanol, and then the resultant mixture was dispersed in an ultrasonic bath for 2 h. $2.5 \mu \mathrm{L}$ of the resulting ink was then pipetted onto glassy carbon electrode (GCE) surface, but before that, the electrode was polished well with $0.05 \mu \mathrm{m}$ alumina pastes followed by ultrasonic cleaning in DI water. The electrode dried at $80^{\circ} \mathrm{C}$ for $1 \mathrm{~h}$ before measurement.

\section{PHYSICAL AND ELECTROCHEMICAL CHARACTERIZATION}

X-ray diffractometer (XRD) analysis was performed with a model Bruker D8 Advance at $40 \mathrm{kV}$ with $\mathrm{CuK} \alpha$ radiation $(\lambda=0.15406 \mathrm{~nm})$. The diffraction angle, $2 \theta$ was recorded from $2-80^{\circ}$ to analyze the crystallinity and crystal phase of catalysts. The morphology of dispersion Ni on MSN was studied using field emission scanning electron microscopy (FESEM Model No. SUPRA 55 VP) and to determine the elements contained in the samples is using EDX, which was attached to the FESEM. To identify the chemical functional groups present in the samples, Fourier Transform Infrared (FT-IR) spectroscopy (Perkin Elmer GX FTIR spectrometer) was carried out. The catalyst was finely ground and dispersed 
into $\mathrm{KBr}$ powder-pressed pellets with a ratio of $1 \mathrm{mg}$ sample to $200 \mathrm{mg} \mathrm{KBr}$. The electrocatalytic activity of the Ni/MSN catalysts towards MOR was evaluated by cyclic voltammetry (CV) in a conventional three-electrode cell. A glassy carbon electrode (GCE) with an area of $0.07068 \mathrm{~cm}^{-2}$ was used as working electrode, a Pt rod was used as the counter electrode, and $\mathrm{Ag} / \mathrm{AgCl}$ was used as reference electrode. $\mathrm{CV}$ experiments were performed in a solution containing electrolyte which is $1.0 \mathrm{M} \mathrm{NaOH}$ in $1 \mathrm{M} \mathrm{CH}_{3} \mathrm{OH}$ as fuel at a scan rate of $50 \mathrm{mVs}^{-1}$. Similar experiments were performed for chronoamperometry (CA) measurements. CA measurements were done at $-0.2 \mathrm{~V}$ for $3600 \mathrm{~s}$.

\section{RESULTS AND DISCUSSION}

\section{STRUCTURAL PROPERTIES}

Figure 1A shows the small angle XRD pattern for the MSN and Ni-MSN in the range $2 \theta=2-10^{\circ}$. The patterns demonstrated three main diffraction peaks shown in the Fig. $1 \mathrm{~A}$ at $2 \theta=$ $2.3,4.1$, and $4.7^{\circ}$ relative to the $\left(\begin{array}{lll}1 & 0 & 0\end{array}\right),\left(\begin{array}{lll}1 & 1 & 0\end{array}\right)$, and $\left(\begin{array}{lll}2 & 0 & 0\end{array}\right)$ reflections respectively, which indexed to a $\mathrm{p} 6 \mathrm{~mm}$ hexagonal structure of mesoporous silica, displaying the high quality of the mesopore packing (Aziz et al. 2014). The ordered MSN support structure was not disturbed by the inclusion of Ni. No shifts in the peaks of the small-angle XRD patterns were observed, but the intensities decreased slightly with the introduction of $\mathrm{Ni}$, indicating minor structural degradation of MSN. The presence of metal crystallites of NiO supported on MSN were characterized using wide-angle XRD patterns $\left(20-80^{\circ}\right)$, as shown in Figure $1 \mathrm{~B}$, in which the diffraction peaks at $37.4,43.4,62.6,75.4$, and 79.4 can be attributed to a face-centered cubic crystalline $\mathrm{NiO}$ (Aziz et al. 2014). The peaks were more intense with the increasing Ni loading $5 \mathrm{wt} \%$, $20 \mathrm{wt} \%$, and $30 \mathrm{wt} \%$, corresponding to a more crystalline phase of $\mathrm{NiO}$ on the MSN support. The inconsistency in $\mathrm{NiO}$ crystal size among the catalysts was mainly due to the surface area of the MSN. Besides, the porous structure of MSN affects the particle size of Ni (Aziz et al. 2014).

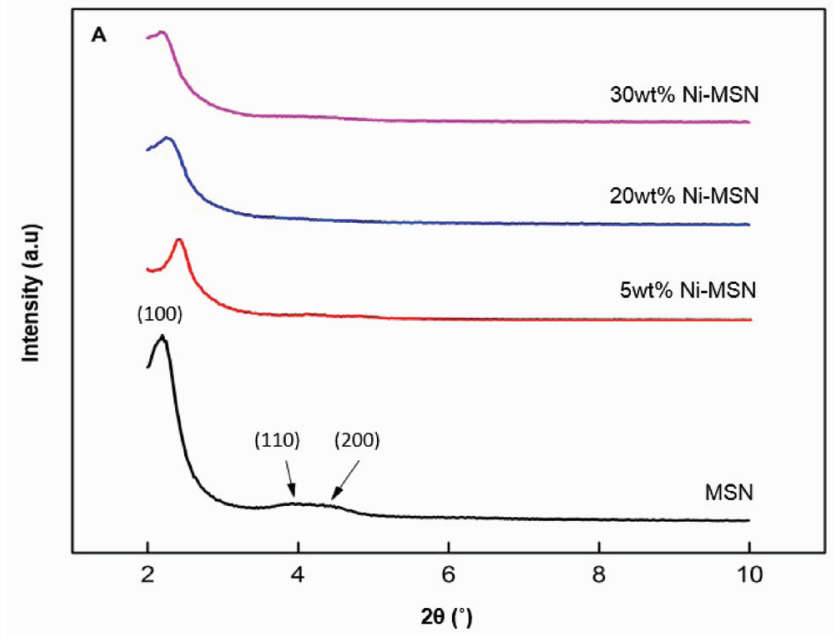

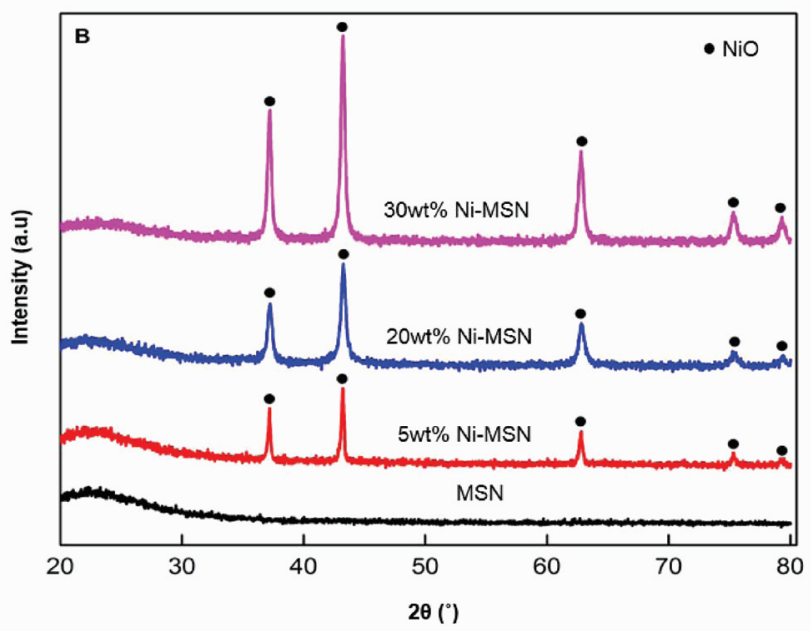

FIGURE 1. Small-angle (A) and wide-angle (B) XRD patterns of MSN, $5 \mathrm{wt} \%$, 20wt $\%$, and $30 \mathrm{wt} \%$ Ni-MSN electrocatalysts

MORPHOLOGICAL CHARACTERIZATION

Figure 2 (A-D) display micrographs of MSN, 5wt $\%$, 20wt $\%$ and $30 \mathrm{wt} \%$ Ni-MSN electrocatalysts with the magnification of 50kX. FESEM micrograph (a) reveals a fairly uniform ordered spherical particles of pure MSN with average diameter of $100 \mathrm{~nm}$, which is consistent with the XRD result (Figure 1). The morphologies of Ni-MSN composites with different loading are shown in Figure (B) to (D). It can be seen that the spherical shape of the MSN was sustained with of Ni loaded onto MSNs and the metal particles have filled up some of the pores (Madzaki et al. 2018). But the shape of MSN was slightly reduced and less aggregated when the $\mathrm{Ni}$ was introduced (Jusoh et al. 2015). The spherical particles with large pores as a catalyst support contributed to an enhanced performance by reducing diffusion limitations, thereby improving the material's electrocatalytic activity for the MOR.

\section{FTIR CHARACTERIZATION}

To confirm the structural changes between the MSN sample and Ni-MSN composites, FT-IR analysis was performed and the results are shown in Figure 3. All Ni-MSNs displayed similar FT-IR spectra with typical patterns of MSN, consisting of bands at 462, 806, 970, 1085, 1646, and $3418 \mathrm{~cm}^{-1}$. From the IR peaks at the bands ascribed is $\mathrm{Si}-\mathrm{O}-\mathrm{Si}\left(462 \mathrm{~cm}^{-1}\right), \mathrm{Si}-$ $\mathrm{O}-\mathrm{Si}$ symmetric stretching $\left(806 \mathrm{~cm}^{-1}\right)$, external $\mathrm{Si}-\mathrm{OH}$ groups $\left(970 \mathrm{~cm}^{-1}\right)$, Si-O-Si asymmetric stretching $\left(1085 \mathrm{~cm}^{-1}\right)$, water molecules retained by siliceous materials $\left(1646 \mathrm{~cm}^{-}\right.$ $\left.{ }^{1}\right)$ and $-\mathrm{OH}$ stretching $\left(3418 \mathrm{~cm}^{-1}\right.$, broad) (Aziz et al. 2014; Karim et al. 2012; Karim et al. 2014). The relative intensity of the IR bands for transmittance is different could be due to the different morphology of the nickel particles (Aziz et al. 2014). Accordingly, the intensity of IR bands decreased when the Ni loading increasing was caused by the presence of a bulk Ni phase. 


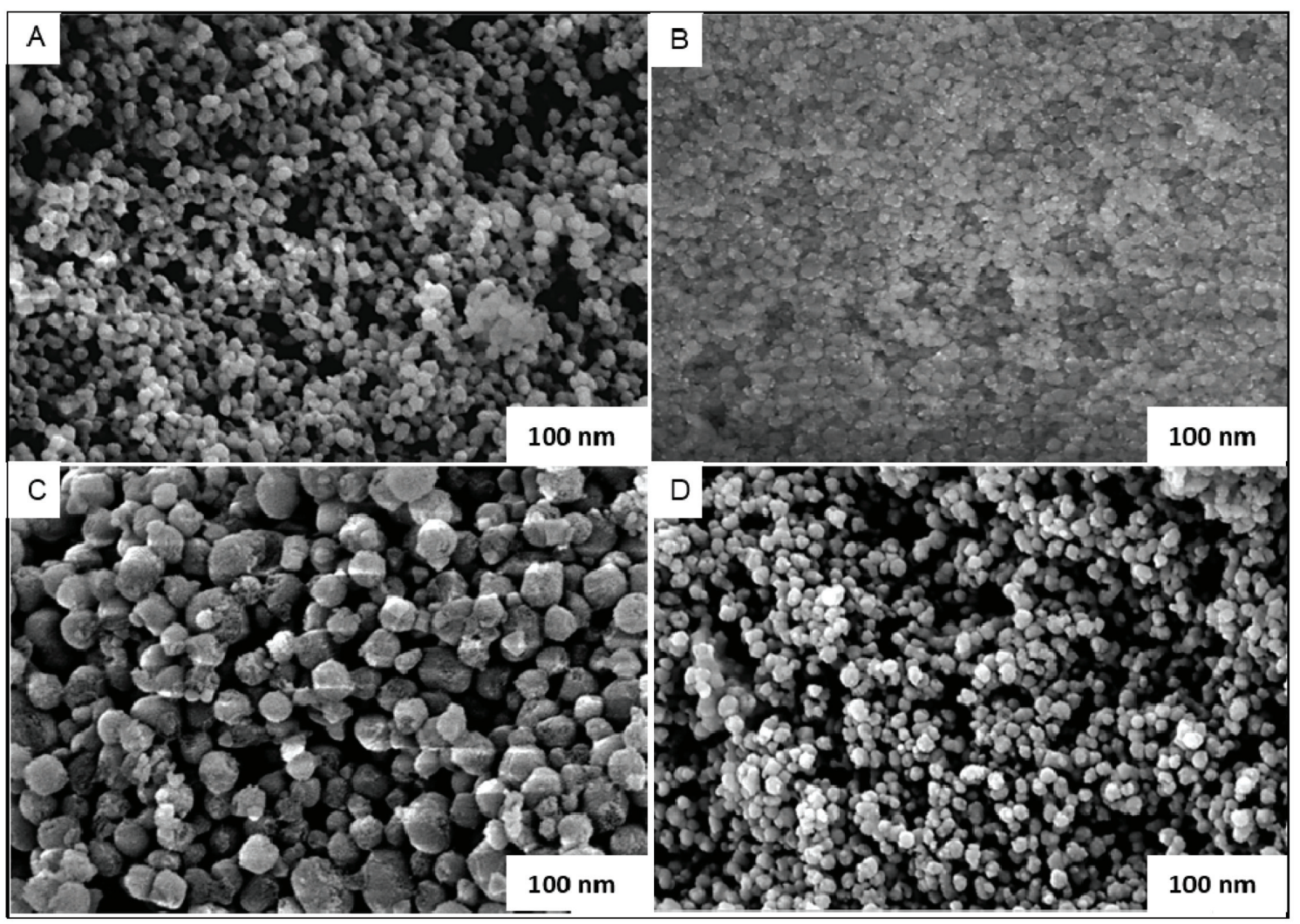

FIGURE 2. FESEM images of MSN (A), $5 \mathrm{wt} \%$ (B), 20wt \% (C), and 30wt \% (D) Ni-MSN electrocatalysts with magnification $50 \mathrm{KX}$

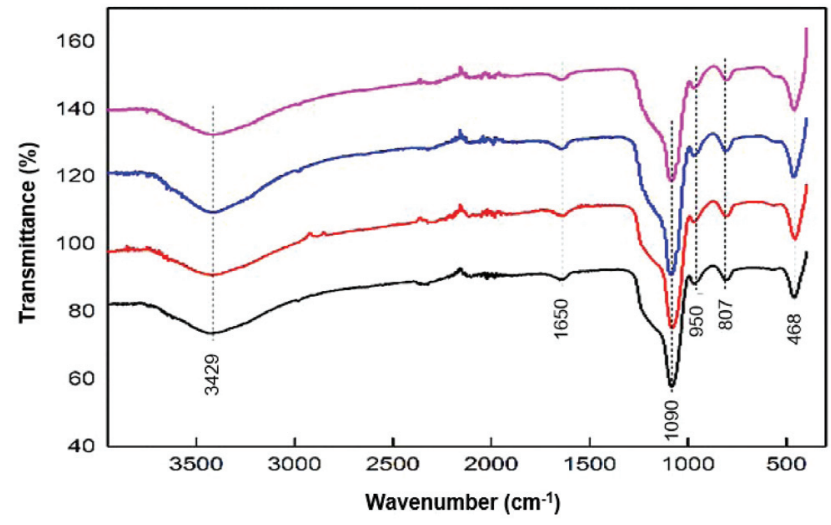

FIGURE 3. FTIR spectra of MSN, $5 w t \%, 20 w t \%$, and $30 w t \%$ Ni-MSN electrocatalysts

ELECTROCHEMICAL CHARACTERIZATION

The cyclic voltammograms of Ni-MSNCPE with different loading of $\mathrm{Ni}$ in $1.0 \mathrm{M} \mathrm{NaOH}$ solution at potential range from -1.0 to $0.5 \mathrm{~V}$ versus $\mathrm{Ag} / \mathrm{AgCl}$ at a scan rate of $50 \mathrm{mV} / \mathrm{s}$ is shown in Figure 4. According to the electrochemical behavior of nickel electrode in the alkaline electrolyte, at potential range from -0.4 to $0.4 \mathrm{~V}$, the conversion of $\alpha-\mathrm{Ni}(\mathrm{OH})_{2}$ to $\beta$ $\mathrm{Ni}(\mathrm{OH})_{2}$ take place (Rahim 2004). $5 \mathrm{wt} \%$ Ni-MSNCPE sample does not show any obvious peak. In voltammograms in Figure 4 , hydrogen evolution takes place at the starting potential characterized by a high anodic current. For sample $20 \mathrm{wt} \%$ $\mathrm{Ni}$-MSNCPE, it can be seen two obvious peaks in the anodic and cathodic direction which at 0.49 and $0.42 \mathrm{~V}$ respectively. While the peak at $0.44 \mathrm{~V}$ in the anodic directions and another peak at $0.36 \mathrm{~V}$ in the cathodic directions for sample $30 \mathrm{wt} \%$ Ni-MSNCPE. This couple of peak attribute to the oxidation of $\mathrm{Ni}(\mathrm{OH})_{2}$ to $\mathrm{NiOOH}$ in accordance with the following reaction in equation 1 (Azizi et al. 2013; Azizi et al. 2013; Rahim 2004):

$$
\begin{gathered}
\mathrm{Ni}(\mathrm{OH})_{2}-\mathrm{MSN}+\mathrm{OH}^{-} \leftrightarrow \mathrm{NiOOH}-\mathrm{MSN}+ \\
\mathrm{H}_{2} \mathrm{O}+\mathrm{e}^{-}
\end{gathered}
$$

The peak at the negative potential side consists of a small anodic peak at a potential value of $-0.47 \mathrm{~V}$ that corresponds to the oxidation of nickel according to the reaction:

$$
\mathrm{Ni}^{2+}+2 \mathrm{OH}^{-} \leftrightarrow \mathrm{Ni}(\mathrm{OH})_{2}
$$

The addition of $1.0 \mathrm{M}$ methanol to the electrolyte made some changes in the voltammetric behavior of the electrode. Figure 5 represents the electrochemical oxidation of $1.0 \mathrm{M}$ $\mathrm{CH}_{3} \mathrm{OH}$ in $1.0 \mathrm{M} \mathrm{NaOH}$ at a scan rate of $50 \mathrm{mV} / \mathrm{s}$. An anodic peak for methanol electrooxidation was taken place with the $\mathrm{NiOOH}$ formation starts to be formed at the onset potential. This indicates the NiOOH species are the active species for methanol electrooxidation. The potential values for $20 \mathrm{wt} \%$ and $30 \mathrm{wt} \% \mathrm{Ni}-\mathrm{MSNCPE}$ are -0.17 and $-0.03 \mathrm{~V}$, respectively. Another oxidation peak for methanol oxidation can be seen in 
the reverse scan but a much smaller value of current density. This peak most likely due to the reoxidation of methanol and/or the intermediate products resulting from the methanol oxidation reaction (Hassan et al. 2014). Among Ni-MSNCPE with different $\mathrm{Ni}$ loadings, 30wt $\%$ Ni-MSNCPE displays the highest current density $\left(\sim 8 \mathrm{~mA} \mathrm{~cm}^{-2}\right)$. In comparison with other studies, wang et al. (Y. Wang et al. 2017) get the peak current density at $7.3 \mathrm{~mA} \mathrm{~cm}{ }^{-2}$ for $\mathrm{Ni} / \mathrm{Al}_{2} \mathrm{O}_{3}$ which is comparable with this study. No obvious current density peak of methanol oxidation on $\mathrm{CV}$ of $5 \mathrm{wt} \% \mathrm{Ni}$-MSNCPE could be observed, which indicates $5 \mathrm{wt} \% \mathrm{Ni}$-MSNCPE is not a sufficient enough of $\mathrm{Ni}$ loading for the electrocatalyst to disperse in mesoporous structure resulted in no electrocatalytic activity in methanol oxidation reaction.

Figure 6 represents chronoamperometry curves for the $5 w t \%, 20 w t \%$ and $30 w t \%$ Ni-MSNCPE in $1.0 \mathrm{M} \mathrm{NaOH}+$ $1.0 \mathrm{M} \mathrm{CH}_{3} \mathrm{OH}$ at a constant potential $-0.2 \mathrm{~V}$ for $3600 \mathrm{~s}$. This test was carried out to compare the long-term stability of the catalysts towards methanol oxidation reaction. In all of the obtained current density vs. time curves, there was an initial drop in the first $500 \mathrm{~s}$ (possibly due to the charging current), followed by a slower decay. The $30 \mathrm{wt} \%$ Ni-MSNCPE electrocatalyst was most active compared with $5 \mathrm{wt} \%$ and 20wt\% Ni-MSNCPE. During the initial and steady current densities of $30 \mathrm{wt} \% \mathrm{Ni}-\mathrm{MSNCPE}$ electrocatalyst 9 times higher than $20 \mathrm{wt} \% \mathrm{Ni}$-MSNCPE in the entire time range used. After a long duration of the reaction, the current gradually decreased for all the catalysts but $30 \mathrm{wt} \%$ maintained a slightly higher current than the other catalysts. For all the catalysts, the current density values decayed with time because of the formation intermediates species due to the applied potential is not positive enough to completely oxidize the reaction intermediates (Hassan et al. 2014). So, it can be concluded that the presence of MSN as a catalyst support for $\mathrm{Ni}$ can enhance the resistance to deactivation caused by the intermediates, resulting in enhanced stability.

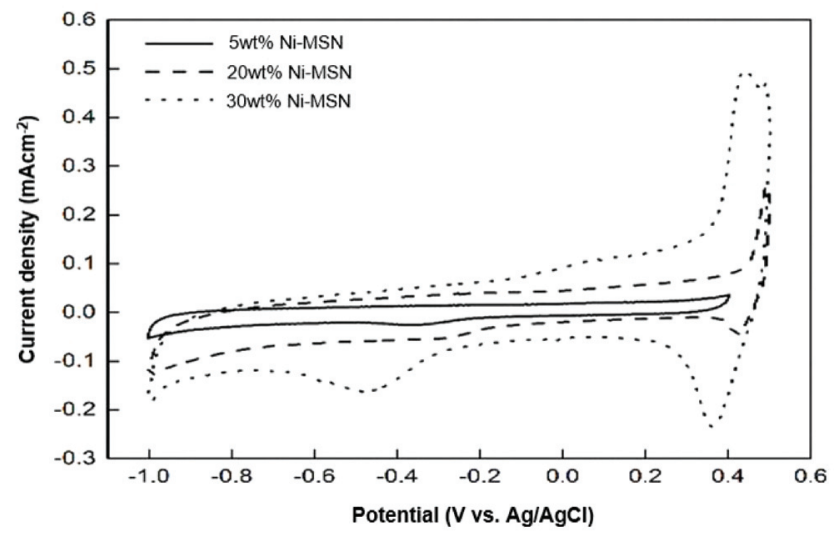

FIGURE 4. Cyclic voltammograms of the $5 \mathrm{wt} \%, 20 \mathrm{wt} \%$, and $30 \mathrm{wt} \%$ Ni-MSNCPE electrocatalysts in $1.0 \mathrm{M} \mathrm{NaOH}$ solution saturated with nitrogen at a scan rate of $50 \mathrm{mV} / \mathrm{s}$.

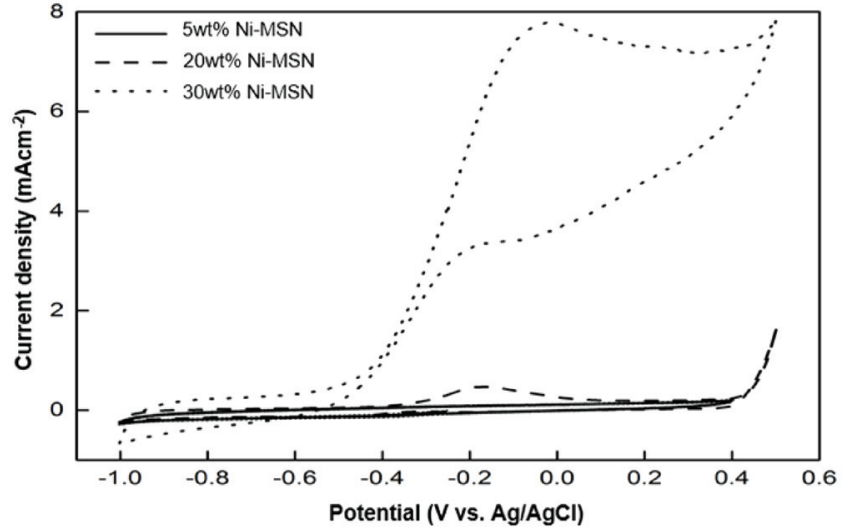

FIGURE 5. Cyclic voltammograms of the $5 \mathrm{wt} \%, 20 \mathrm{wt} \%$, and $30 \mathrm{wt} \% \mathrm{Ni}$-MSNCPE electrocatalysts in $1.0 \mathrm{M} \mathrm{NaOH}+1.0 \mathrm{M}$ $\mathrm{CH}_{3} \mathrm{OH}$ solution saturated with nitrogen at a scan rate of $50 \mathrm{mV} / \mathrm{s}$

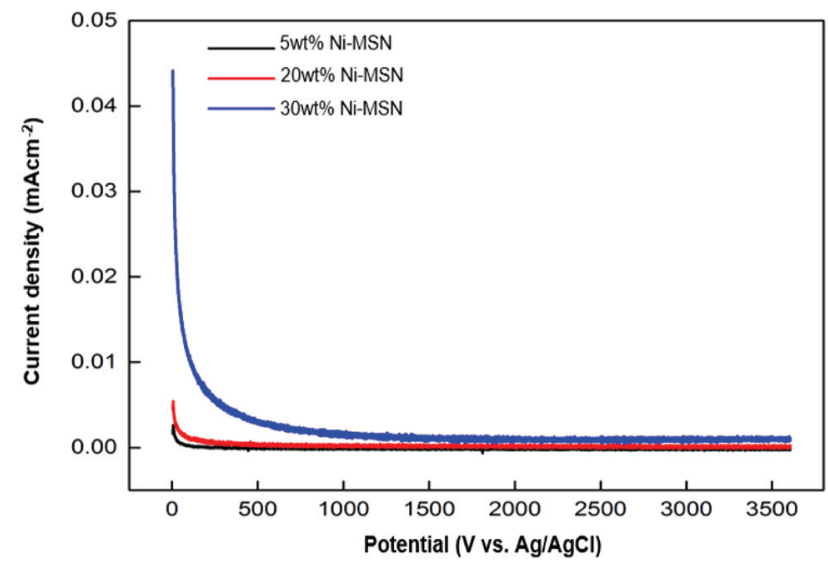

FIGURE 6. Chronoamperometry of the $5 \mathrm{wt} \%$, 20wt $\%$, and $30 \mathrm{wt} \%$ Ni-MSNCPE electrocatalysts in $1.0 \mathrm{M} \mathrm{NaOH}+1.0 \mathrm{M} \mathrm{CH}_{3} \mathrm{OH}$ solution saturated with nitrogen at $\mathrm{E}=-0.2 \mathrm{~V}$

\section{CONCLUSION}

In this work, $5 \mathrm{wt} \%, 20 \mathrm{wt} \%$, and $30 \mathrm{wt} \% \mathrm{Ni} / \mathrm{MSN}$ catalysts were prepared by the wet impregnation method. XRD results indicate that $\mathrm{Ni} / \mathrm{MSN}$ catalysts obtain a high quality of the mesopore packing and hexagonal structure of mesoporous silica. FESEM results show that an ordered mesostructured of pure MSN and highly porous structure of MSN. When Ni is load onto MSN the particle size was reduced. Based on FTIR results, it could be suggested that the intensity of IR bands decreased when the Ni loading increasing was caused by the presence of a bulk Ni phase. As a catalyst for methanol oxidation in alkaline medium, 30 wt $\%$ Ni-MSNCPE reveals a higher current density $\sim 8 \mathrm{~mA} \mathrm{~cm}^{-2}$, most stable (3600 s), which surpass many state-of-art Ni-based catalysts. The remarkable catalytic performance of the $30 \mathrm{wt} \% \mathrm{Ni}$-MSNCPE electrocatalyst is due to its unique structure, morphology, and composition. 


\section{ACKNOWLEDGEMENT}

The authors acknowledge the financial support provided by Ministry of Higher Education, Malaysia through Fundamental Research Grant Scheme (FRGS) no. FRGS/1/2016/STG07/ $\mathrm{UKM} / 03 / 2$.

\section{REFERENCES}

Antolini, E. \& Gonzalez, E. R. 2010. Alkaline direct alcohol fuel cells. Journal of Power Sources 195(11): 34313450 .

Aziz, M. A. A., Jalil, A. A., Triwahyono, S., Mukti, R. R., Taufiq-Yap, Y. H. \& Sazegar, M. R. 2014. Highly active Ni-promoted mesostructured silica nanoparticles for $\mathrm{CO}_{2}$ methanation. Applied Catalysis B: Environmental, 147: 359-368

Aziz, M. A. A., Jalil, A. A., Triwahyono, S. \& Saad, M. W. A. 2014. $\mathrm{CO}_{2}$ methanation over Ni-promoted mesostructured silica nanoparticles: Influence of $\mathrm{Ni}$ loading and water vapor on activity and response surface methodology studies. Chemical Engineering Journal 260: 757-764.

Azizi, S. N., Ghasemi, S. \& Chiani, E. 2013. Nickel/ mesoporous silica (SBA-15) modified electrode: An effective porous material for electrooxidation of methanol. Electrochimica Acta 88: 463-472.

Azizi, S. N., Ghasemi, S. \& Yazdani-Sheldarrei, H. 2013. Synthesis of mesoporous silica (SBA-16) nanoparticles using silica extracted from stem cane ash and its application in electrocatalytic oxidation of methanol. International Journal of Hydrogen Energy 38(29): 12774-12785.

Danaee, I., Jafarian, M., Mirzapoor, A., Gobal, F. \& Mahjani, M. G. 2010. Electrooxidation of methanol on NiMn alloy modified graphite electrode. Electrochimica Acta 55(6): 2093-2100.

El-Shafei, A. A. 1999. Electrocatalytic oxidation of methanol at a nickel hydroxide / glassy carbon modified electrode in alkaline medium. Journal of Electroanalytical Chemistry 471: 89-95.

Hassan, H. B., Rahim, M. A. A., Khalil, M. W. \& Mohammed, R. F. 2014. Ni modified MCM-41 as a catalyst for direct methanol fuel cells. International Journal of Electrochemical Science 9(2): 760-777.

Jusoh, N. W. C., Jalil, A. A., Triwahyono, S., Karim, A. H., Salleh, N. F., Annuar, N. H. R., Jaafar, N. F., Firmansyah, M. L., Mukti, R. R. \& Ali, M.W. 2015. Structural rearrangement of mesostructured silica nanoparticles incorporated with $\mathrm{ZnO}$ catalyst and its photoactivity: Effect of alkaline aqueous electrolyte concentration. Applied Surface Science 330: 10-19.

Kamarudin, S. K., Wan Daud, W. R., Md. Som, A. \& Masdar, M. S. 2006. Conceptual Design of $5 \mathrm{~kW}$ PEM fuel cell stack. Jurnal Kejuruteraan 19: 43-54.
Karim, A. H., Jalil, A. A., Triwahyono, S., Kamarudin, N. H. N. \& Ripin, A. 2014. Influence of multi-walled carbon nanotubes on textural and adsorption characteristics of in situ synthesized mesostructured silica. Journal of Colloid and Interface Science 421: 93-102.

Karim, A. H., Jalil, A. A., Triwahyono, S., Sidik, S. M., Kamarudin, N. H. N., Jusoh, R., Jusoh, N. W. C. \& Hameed, B. H. 2012. Amino modified mesostructured silica nanoparticles for efficient adsorption of methylene blue. Journal of Colloid And Interface Science 386(1): 307-314.

Liu, D., Chen, T. \& Zhu, W. 2016. Cobalt phosphide nanowall array as an efficient 3D catalyst electrode for methanol. Nanotechnology, 27(44). Artikel ID: 44LT02

Madzaki, H., Wan Ab Karim Ghani, W. A. \& Choong Shean Yaw, T. 2018. Carbon dioxide adsorption on activated carbon hydrothermally treated and impregnated with metal oxides. Jurnal Kejuruteraan 30(1): 31-38.

Patel, P. P., Datta, M. K., Jampani, P. H., Hong, D., Poston, J. A., Manivannan, A. \& Kumta, P. N. 2015. High performance and durable nanostructured TiN supported Pt50-Ru50 anode catalyst for direct methanol fuel cell (DMFC). Journal of Power Sources 293: 437-446.

Peng, M., Sun, X. \& Asiri, A. M. 2015. In situ growth of nickel selenide nanowire arrays on nickel foil for methanol electro-oxidation in alkaline media. RSC Advances, 5: 87051-87054.

Rahim, A. 2004. Nickel as a catalyst for the electro-oxidation of methanol in alkaline medium of methanol in alkaline medium. Journal of Power Sources 134: 160-169.

Ting, L., Shyuan, K., Bakar, A., Ramli, W. \& Daud, W. 2016. Synthesis of silver / nitrogen-doped reduced graphene oxide through a one-step thermal solid-state reaction for oxygen reduction in an alkaline medium. Journal of Power Sources 324: 412-420.

Tong, Y. Y., Gu, C. D., Zhang, J. L., Tang, H., Wang, X. L. \& $\mathrm{Tu}, \mathrm{J}$. P. 2016. Thermal growth of $\mathrm{NiO}$ on interconnected Ni-P tube network for electrochemical oxidation of methanol in alkaline medium. International Journal of Hydrogen Energy 41: 6342-6352.

Wang, L., Zhang, G., Liu, Y., Li, W., Lu, W. \& Huang, H. 2016. Facile synthesis of a mechanically robust and highly porous $\mathrm{NiO}$ film with excellent electrocatalytic activity towards methanol oxidation. Nanoscale 8: 11256-11263.

Wang, Y., Chen, W., Pang, D. \& Xu, Q. 2017. Methanol electrooxidation reaction in alkaline medium on glassy carbon electrode modified with ordered mesoporous. International Journal of Electrochemical Science 12: 2194-2206.

Zainoodin, A. M., Kamarudin, S. K. \& Daud, W. R. W. 2010. Electrode in direct methanol fuel cells. International Journal of Hydrogen Energy 35(10): 4606-4621.

Zhao, X., Yin, M., Ma, L., Liang, L., Liu, C. \& Liao, J. 2011. Recent advances in catalysts for direct methanol fuel cells. Energy Environmental Science 4: 2736-2753. 
*Sharifah Najiha Timmiati

Fuel Cell Institute,

Universiti Kebangsaan Malaysia, Bangi, Malaysia.

Muliani Mansor, Kean Long Lim, Azran Mohd Zainoodin

Fuel Cell Institute,

Universiti Kebangsaan Malaysia, Bangi, Malaysia.

Nur Hidayatul Nazirah Kamarudin Department of

Chemical and Process Engineering, Faculty of

Engineering \& Built Environment, Universiti

Kebangsaan Malaysia, Bangi, Malaysia.

Corresponding author; email: najiha@ukm.edu.my

Received date: $25^{\text {th }}$ May 2017

Accepted date: $13^{\text {th }}$ September 2018

Online first date: $1^{\text {st }}$ October 2018

Published date: $30^{\text {th }}$ November 2018 